JPPKMI 2 (2) (2021)
JURNAL PENELITIAN DAN PENGEMBANGAN
KESEHATAN MASYARAKAT INDONESIA
Jttps://journal.unnes.ac.id/sju/index.php/jppkmi

\title{
Pola Makan dan Kebiasaan Olahraga Remaja
}

\author{
Aisyah Nur Fauziyyah ${ }^{1}$, Mustakim $^{1} \bowtie$, Intan Rosenanda Sofiany $^{1}$ \\ ${ }^{1}$ Fakultas Kesehatan Masyarakat, Universitas Muhammadiyah Jakarta, Indonesia
}

\section{Info Artikel}

Sejarah Artikel:

Diterima Juli 2021

Disetujui November 2021

Dipublikasi Desember 2021

\section{Keywords:}

Exercise Habits, Dietary

Patterns, Adolescent

$U R L:$

https://iournal.unnes.ac.

d/siu/index.php/ippkmi /article/view/51971

\begin{abstract}
Abstrak
Saat ini, remaja menjadi kelompok yang rentan menghadapi beban ganda malnutrisi. Hasil Riskesdas 2018 menunjukkan penduduk usia 13-18 tahun memiliki masalah gizi pendek (52.6\%), kurus $(16.8 \%)$ dan kegemukan $(29.5 \%)$. Pola makan dan kebiasaan olahraga remaja sebagai prediktor status gizi juga memprihatinkan. Sebanyak $97.5 \%$ remaja belum mencukupi asupan energi harian sesuai AKG dan 52.6\% remaja memiliki kebiasaan olahraga rendah. Penelitian ini bertujuan untuk mengidentifikasi pola makan dan kebiasaan olahraga pada kelompok remaja. Metode penelitian yang digunakan yakni deskriptif kuantitatif dengan desain studi potong lintang dan dilakukan pada bulan April-Agustus 2021 di SMA Dewan Da'wah Bekasi. Total sampel penelitian berjumlah 46 responden. Hasil penelitian menunjukkan sebagian besar responden usia remaja memiliki asupan energi (71.7\%), karbohidrat (78.3\%) dan protein (67.4\%) yang inadekuat. Didapatkan separuh jumlah responden memiliki asupan lemak yang inadekuat $(50 \%)$. Sebagian besar responden makan dengan frekuensi 3 kali/hari (89.1\%). Mayoritas responden penelitian juga memiliki kebiasaan olahraga yang kurang aktif (80.4\%). Simpulan dalam penelitian ini menunjukkan kelompok remaja memiliki pola makan yang inadekuat dan kebiasaan olahraga yang kurang aktif.
\end{abstract}

\begin{abstract}
Adolescents are vulnerable group to triple burden of malnutrition. Riskesdas 2018 showed that adolescents group (13-18 years old) have nutrition problems, such as stunted (52.6\%), wasting (16.8\%) and overweight $(29.5 \%)$. Diet and exercise habits as predictors of adolescents nutritional status also showed bad numbers. As many as $97.5 \%$ adolescents didn't have sufficient daily energy intake according to the AKG and $52.6 \%$ of adolescents have low exercise habits. This study aims to determine diet and exercise habits of the adolescent group. The research design used was descriptive quantitative with a cross sectional approach and carried out in April-August 2021 in Dewan Da'wah Senior High School Bekasi district. The research sample was 46 respondents. The results showed that most of the adolescents had inadequate energy (71.7\%), carbohydrates $(78.3 \%)$ and protein (67.4\%) intake. Half of respondents had inadequate fat intake (50\%). Most of respondents eat 3 times/day. The majority of respondents also have less exercise habits (80.4\%). The conclusion in this study showed that adolescents has inadequate diet and less exercise habits.
\end{abstract}

\footnotetext{
Alamat korespondensi:

J1. K.H. Ahmad Dahlan, Cireundeu, Kec. Ciputat,

Kota Tangerang Selatan, Banten 15419

E-mail: mustakim@umi.ac.id
} 


\section{PENDAHULUAN}

Beban ganda malnutrisi (Triple burden of malnutrition) masih menjadi persoalan yang belum dapat teratasi di Indonesia. Faktanya, negara ini terus dihadapkan dengan masalah kurang gizi, kelebihan berat badan hingga defisiensi zat gizi mikro (Rah, 2021). Diantara kelompok yang rentan menanggung beban tersebut ialah remaja, yang tengah mengalami fase pubertas dan pacu tumbuh (growth spurt) (United Nations Children's Fund, 2020). Data Riset Kesehatan Dasar Tahun 2018 memberikan gambaran beberapa masalah gizi pada kelompok remaja. Kelompok remaja berusia 1318 tahun dilaporkan memiliki prevalensi pendek sebesar 52.6\%, prevalensi kurus sebesar 16.8\% dan di sisi lain, terdapat peningkatan masalah kegemukan dibandingkan tahun 2013 sehingga prevalensinya menjadi 29.5\% (Badan Penelitian dan Pengembangan Kesehatan, 2019).

Rentannya kondisi malnutrisi pada remaja mengindikasikan pentingnya pemenuhan gizi berkualitas guna mengoptimalkan fase perkembangan fisik dan kognitif (United Nations Children's Fund, 2020). Terpenuhinya kebutuhan gizi remaja bermanfaat dalam menstabilkan berat badan, melindungi tubuh dari infeksi, meningkatkan produktivitas hingga mengurangi risiko penyakit kronis yang berkaitan dengan gizi. Sebaliknya, pemenuhan gizi yang inadekuat berkaitan dengan terhambatnya pertumbuhan serta potensi fisik dan kognitif, menurunnya kondisi kesehatan hingga meningkatkan risiko penyakit tidak menular saat dewasa, seperti penyakit kardiovaskular, obesitas dan lain-lain (Kumala, 2014). Diantara faktor yang turut berkontribusi besar terhadap kondisi gizi remaja ialah pola makan rendah gizi dan perilaku minim gerak (sedenter) (United Nations Children's Fund, 2020).

United Nations Children's Fund (2020) melaporkan terdapat perubahan pola asupan makanan remaja di Indonesia yang mengalami peningkatan konsumsi lemak dan makanan olahan hingga dua kali lipat. Keragaman pangan remaja di Indonesia juga dikategorikan buruk, hanya $25 \%$ yang mengkonsumsi sumber zat besi dan zat gizi mikro penting dari sumber hewani dan nabati. Studi terhadap kelompok remaja juga mengungkapkan $57.6 \%$ responden memiliki pola makan tidak sesuai PUGS dan $57.6 \%$ responden kurang mengkonsumsi buah (Suci, 2011). Studi lain juga mengungkapkan terdapat $97.5 \%$ remaja yang belum mencukupi konsumsi energi harian sesuai AKG (Mokoginta, 2016). Di sisi lain, tingkat aktivitas fisik remaja juga ditemukan sangat minim, yakni kurang dari 90 menit/minggu (United Nations Children's Fund, 2021). Studi Setiawati (2019) melaporkan terdapat $52.6 \%$ responden yang memiliki kebiasaan olahraga rendah $(<600$ METs/menit).

Pola makan merupakan susunan makanan yang mencakup jenis dan jumlah bahan makanan rata-rata per orang per hari yang secara umum dikonsumsi masyarakat dalam jangka waktu tertentu (Sirajuddin, 2018). Pola makan menjadi perilaku fundamental yang berpengaruh langsung terhadap keadaan gizi individu, karena kuantitas dan kualitas makanan dan minuman yang dikonsumsi dapat mempengaruhi asupan gizi sehingga berdampak pada kondisi kesehatan.

Olahraga (exercise) merupakan salah satu bagian dari aktivitas fisik yang melibatkan gerakan tubuh berulang-ulang dan dilakukan secara terencana dan terstruktur, bertujuan untuk memperbaiki dan mempertahankan satu atau lebih komponen kebugaran fisik seseorang. Aktivitas fisik sendiri diartikan sebagai setiap gerakan tubuh yang dihasilkan otot rangka yang membutuhkan energi untuk mengerjakannya (Kusumo, 2020). Aktivitas fisik termasuk olahraga menjadi salah satu faktor yang berpengaruh pada status gizi individu. Hal ini dikarenakan olahraga mampu meningkatkan metabolisme tubuh yang menyebabkan cadangan energi dalam tubuh berupa lemak dapat terbakar sebagai kalori (Roring, 2020).

Remaja merupakan masa peralihan dari masa kanak-kanak menuju dewasa. Pada fase tersebut, individu mengalami perubahan yang sangat cepat, meliputi perubahan fisik, kognitif dan psikososial sehingga membutuhkan asupan gizi yang lebih tinggi (Hafiza, 2020). Pola 
konsumsi remaja akan menentukan jumlah zat gizi yang diperlukan guna pertumbuhan dan perkembangan. Pola konsumsi yang tidak adekuat akan mempengaruhi asupan zat gizi sehingga berdampak pada pertumbuhan dan perkembangan tidak optimal serta meningkatkan kerentanan terhadap penyakit kronis di masa dewasa (Mokoginta, 2016).

Studi pendahuluan yang dilakukan peneliti menemukan sebagian pelajar SMA Dewan Da'wah memiliki berat badan berlebih. Hal ini dapat disebabkan kebijakan belajar dari rumah yang diberlakukan selama pandemi COVID-19 sehingga berdampak pada asupan makan berlebih dan meningkatnya status gizi. Longgarnya waktu luang dan minimnya aktivitas fisik di rumah juga dapat berkontribusi pada kondisi tersebut. Masih minimnya studi yang mengidentifikasi pola makan dan kebiasaan olahraga pada remaja selama pemberlakuan kebijakan belajar dari rumah menjadikan penelitian ini penting dilakukan. Berangkat dari latar belakang tersebut, penelitian ini dilakukan untuk mengidentifikasi pola makan dan kebiasaan olahraga remaja di SMA Dewan Da'wah Kabupaten Bekasi Tahun 2021.

\section{METODE}

Penelitian ini menggunakan metode kuantitatif deskriptif dengan desain studi potong lintang (Cross sectional). Penelitian dilaksanakan pada bulan April-Agustus tahun 2021 dan berlokasi di SMA Dewan Da'wah Kabupaten Bekasi. Variabel dalam penelitian ini terdiri dari pola makan dan kebiasaan olahraga. Variabel pola makan diukur menggunakan instrumen food recall $2 \times 24$ hour yang memuat jenis makanan yang dikonsumsi selama satu hari disertai ukuran makan menggunakan standar Ukuran Rumah Tangga (URT). Variabel kebiasaan olahraga diukur menggunakan instrument APARQ (Adolescent Physical Activity Recall Questionnaire) yang memuat frekuensi dan durasi aktivitas olahraga. Populasi dalam penelitian ini ialah seluruh siswa/I kelas X-XII SMA Dewan Da'wah Kabupaten Bekasi yang tengah mengikuti kegiatan belajar dari rumah. Metode pengambilan sampel yang digunakan ialah total sampling. Jumlah keseluruhan sampel yang berpartisipasi sebanyak 46 responden. Pengumpulan data dilakukan dengan menyebarkan kuesioner penelitian secara daring menggunakan platform google form. Pengisian kuesioner dilakukan secara mandiri oleh responden (self administered). Food model juga dilampirkan di kuesioner guna memudahkan responden dalam menjawab pertanyaan. Data primer dalam penelitian ini meliputi identitas responden, gambaran pola makan dan gambaran kebiasaan olahraga. Data sekunder digunakan untuk mengetahui jumlah dan karakteristik sasaran penelitian. Data food recall yang terkumpul dilakukan konversi dan diolah menggunakan Nutrisurvey. Data kebiasaan olahraga dilakukan skoring sesuai standar yang terdapat pada daftar METs (Metabolic Equivalent Task). Analisis data dilakukan secara univariat menggunakan uji statistik deskriptif.

\section{HASIL DAN PEMBAHASAN}

Data pada Tabel 1. menggambarkan distribusi responden berdasarkan karakteristik. Berdasarkan jenis kelamin, lebih dari separuh jumlah responden penelitian berjenis kelamin laki-laki (58.7\%) dan sebanyak $41.3 \%$ responden berjenis kelamin perempuan. Selanjutnya, berdasarkan usia, terdapat $54.3 \%$ responden berusia $>16$ tahun dan $45.7 \%$ responden berusia $\leq 16$ tahun.

Data pada Tabel 2. menggambarkan distribusi responden berdasarkan kecukupan zat gizi, yang terbagi menjadi kecukupan energi, kecukupan karbohidrat, kecukupan

Tabel 1. Distribusi Responden Berdasarkan Karakteristik

\begin{tabular}{lll}
$\begin{array}{l}\text { Karakteristik } \\
\text { Responden }\end{array}$ & $\begin{array}{l}\text { Jumlah } \\
(\mathrm{n}=46)\end{array}$ & $\begin{array}{l}\text { Persentase } \\
(\%)\end{array}$ \\
$\begin{array}{l}\text { Jenis Kelamin } \\
\text { Laki-laki }\end{array}$ & 27 & 58.7 \\
$\begin{array}{l}\text { Perempuan } \\
\text { Usia }\end{array}$ & 19 & 41.3 \\
$\leq 16$ Tahun & 21 & 45.7 \\
$\geq 16$ Tahun & 25 & 54.3 \\
\hline
\end{tabular}


Tabel 2. Distribusi Responden Berdasarkan Kecukupan Zat Gizi

\begin{tabular}{|c|c|c|c|}
\hline $\begin{array}{l}\text { Kecukupan } \\
\text { Gizi }\end{array}$ & Zat & $\begin{array}{l}\text { Jumlah } \\
(\mathrm{n}=46)\end{array}$ & $\begin{array}{l}\text { Persentase } \\
\text { (\%) }\end{array}$ \\
\hline \multicolumn{4}{|c|}{ Asupan Energi } \\
\hline Kurang & $(<80 \%$ & 33 & 71.7 \\
\hline AKG) & & 13 & 28.3 \\
\hline Cukup & $(\geq 80 \%$ & & \\
\hline \multicolumn{4}{|l|}{ AKG) } \\
\hline \multicolumn{4}{|l|}{ Asupan } \\
\hline \multicolumn{2}{|c|}{ Karbohidrat } & 36 & 78.3 \\
\hline Kurang & $(<80 \%$ & 10 & 21.7 \\
\hline \multicolumn{2}{|l|}{ AKG) } & & \\
\hline \multicolumn{4}{|l|}{ Cukup } \\
\hline \multicolumn{4}{|c|}{ AKG) } \\
\hline \multicolumn{4}{|c|}{ Asupan Protein } \\
\hline Kurang & $(<80 \%$ & 31 & 67.4 \\
\hline AKG) & & 15 & 32.6 \\
\hline Cukup & $(\geq 80 \%$ & & \\
\hline AKG) & & & \\
\hline \multicolumn{4}{|c|}{ Asupan Lemak } \\
\hline Kurang & $(<80 \%$ & 23 & 50 \\
\hline AKG) & & 23 & 50 \\
\hline Cukup & $(\geq 80 \%$ & & \\
\hline AKG) & & & \\
\hline
\end{tabular}

protein dan kecukupan lemak. Berdasarkan data yang diperoleh, sebanyak $71.7 \%$ responden memiliki tingkat kecukupan energi kurang $(<80 \%$ AKG) dan $28.3 \%$ responden memiliki tingkat kecukupan energi cukup. Berdasarkan konsumsi karbohidrat, sebagian besar responden (78.3\%) memiliki tingkat kecukupan karbohidrat kurang ( $<80 \%$ AKG) dan $21.7 \%$ responden memiliki tingkat kecukupan karbohidrat dalam kategori cukup. Selanjutnya didapatkan lebih dari separuh jumlah responden (67.4\%) memiliki tingkat kecukupan protein dalam kategori kurang sementara $32.6 \%$ responden lainnya memiliki tingkat kecukupan protein dalam kategori cukup. Berdasarkan konsumsi lemak, sebanyak $50 \%$ responden memiliki tingkat kecukupan lemak dalam kategori kurang dan $50 \%$ responden lainnya memiliki tingkat kecukupan lemak dalam kategori cukup.

Data pada Tabel 3. menggambarkan distribusi responden berdasarkan frekuensi makan. Frekuensi makan responden terbagi menjadi dua kategori, yakni cukup (3 kali/hari) dan kurang ( $<3 \mathrm{kali} / \mathrm{hari})$. Berdasarkan data yang diperoleh, mayoritas responden (89.1\%) memiliki frekuensi makan dalam kategori
Tabel 3. Distribusi Responden Berdasarkan Frekuensi Makan

\begin{tabular}{|c|c|c|}
\hline Frekuensi Makan & Jumlah & $\begin{array}{l}\text { Persentase } \\
(\%)\end{array}$ \\
\hline Kurang $\quad(<3$ & 5 & \\
\hline kali/hari) & 41 & $\begin{array}{l}10.9 \\
89.1\end{array}$ \\
\hline Total & 46 & 100 \\
\hline
\end{tabular}

Tabel 4. Distribusi Responden Berdasarkan Kebiasaan Olahraga

\begin{tabular}{lll}
\hline Kebiasaan Olahraga & Jumlah & $\begin{array}{l}\text { Persentase } \\
(\%)\end{array}$ \\
$\begin{array}{l}\text { Kurang Aktif }(<467.28 \\
\text { METs/menit/minggu) }\end{array}$ & 37 & 80.4 \\
$\begin{array}{l}\text { Aktif } \quad \geq 467.28 \\
\text { METs/menit/minggu) }\end{array}$ & 9 & 19.6 \\
Total & 46 & 100 \\
\hline
\end{tabular}

cukup, yakni 3 kali/hari dan sebanyak 10.9\% responden memiliki frekuensi makan kurang, yakni $<3$ kali/hari.

Data pada Tabel 4. menggambarkan distribusi responden berdasarkan kebiasaan olahraga. Kebiasaan olahraga responden terbagi menjadi dua kategori, yakni kurang aktif (Skor METs $<467.28 / \mathrm{menit} / \mathrm{minggu}$ ) dan aktif (Skor METs $\geq 467.28 / \mathrm{menit} / \mathrm{minggu}$ ). Berdasarkan data yang diperoleh, diketahui mayoritas responden $(80.4 \%)$ memiliki kebiasaan olahraga kurang aktif (Skor METs $<467.28 / \mathrm{menit} / \mathrm{minggu})$ dan terdapat $19.6 \%$ responden yang aktif berolahraga dengan skor METs $\geq 467.28 / \mathrm{menit} / \mathrm{minggu}$.

Berdasarkan data asupan zat gizi yang diperoleh, diketahui bahwa sebagian besar responden memiliki kekurangan asupan energi (71.7\%), karbohidrat (78.3\%) dan protein (67.4\%). Selanjutnya terdapat separuh jumlah responden $(50 \%)$ yang memiliki kekurangan asupan lemak. Hasil dalam penelitian ini sejalan dengan studi Amelia (2013) terhadap kelompok remaja yang menunjukkan $87 \%$ responden kekurangan asupan energi, $34 \%$ responden kekurangan asupan protein, $10 \%$ responden kekurangan asupan lemak dan 99\% responden kekurangan asupan karbohidrat. Pada studi Rokhmah (2016) juga ditemukan hasil serupa, yakni tingkat kecukupan energi mayoritas responden adalah inadekuat $(71 \%)$. Selanjutnya, 
mayoritas responden juga memiliki tingkat kecukupan zat gizi makro yang inadekuat (protein 67\%, lemak 71\% dan karbohidrat 64\%). Studi terbaru oleh Sholichah (2021) juga menunjukkan sebagian besar kelompok remaja memiliki asupan energi, karbohidrat, protein dan lemak yang cenderung kurang dari kebutuhan berdasarkan Angka Kecukupan Gizi (AKG) yang dianjurkan. Dalam penelitian tersebut diketahui bahwa seluruh responden memiliki asupan energi dan karbohidrat $<80 \%$ kebutuhan yang dianjurkan.

Faktor yang dapat berkontribusi terhadap kurangnya asupan energi pada kelompok remaja diantaranya kebiasaan mengkonsumsi makanan selingan atau kudapan yang minim zat gizi, seperti kerupuk, cireng, permen dan makanan kemasan. Sebagian besar makanan selingan tersebut tidak hanya hampa kalori, namun juga minim zat gizi dan dapat mengganggu nafsu makan (Rokhmah, 2016). Survei yang menganalisa kebiasaan, wawasan dan tren konsumsi makanan selingan di Indonesia menemukan bahwa masyarakat cenderung lebih sering mengkonsumsi makanan selingan dibandingkan makanan utama (Mondelez International and The Harris Poll, 2020).

Seyogyanya, pemenuhan kecukupan energi dan zat gizi makro sangat penting pada usia remaja. Asupan energi dibutuhkan tubuh untuk proses pertumbuhan, metabolisme, utilisasi bahan makanan dan aktivitas. Tingkat kecukupan energi yang merupakan hasil metabolisme zat gizi makro sangat bergantung pada asupan karbohidrat, protein dan lemak. Ketidakseimbangan tingkat kecukupan zat gizi dapat menimbulkan masalah gizi (Rokhmah, 2016). Jika asupan energi kurang dari kecukupan yang dibutuhkan, cadangan energi yang tersimpan di otot akan digunakan. Selain itu, protein juga akan digunakan sebagai energi apabila konsumsi energi terbatas. Kekurangan energi berkelanjutan dapat menyebabkan penurunan berat badan dan berdampak pada status gizi hingga mempengaruhi proses pertumbuhan (Utami, 2020).

Pemenuhan kebutuhan karbohidrat individu utamanya diperoleh dari konsumsi makanan pokok. Asupan karbohidrat dapat mempengaruhi status gizi individu karena jumlah konsumsi karbohidrat dapat meningkatkan jumlah energi secara signifikan. Selanjutnya, pemenuhan kebutuhan protein dan lemak utamanya diperoleh dari lauk pauk hewani maupun nabati.

Kebutuhan protein pada masa remaja mencapai angka tertinggi karena dibutuhkan guna mempertahankan dan meningkatkan massa tubuh tanpa lemak selama masa pertumbuhan. Kekurangan protein dalam jangka waktu lama dapat menurunkan daya tahan tubuh terhadap penyakit, pertumbuhan linear yang kurang optimal hingga keterlambatan maturasi (kematangan) seksual. Asupan lemak juga berkontribusi besar dalam menghasilkan energi. Apabila tingkat kecukupan lemak dalam kategori inadekuat, maka besar kemungkinan tingkat kecukupan energi juga inadekuat (Rokhmah, 2016; Sholichah, 2021).

Berdasarkan indikator frekuensi makan, mayoritas responden (89.1\%) memiliki frekuensi makan 3 kali/hari dan digolongkan pada kategori cukup. Hasil ini sejalan dengan studi Amaliyah (2021) yang menunjukkan lebih dari separuh jumlah responden (59\%) memiliki frekuensi makan $3 \mathrm{kali} /$ hari dengan pembagian waktu makan pagi, siang dan malam. Studi Anggraeni (2015) juga melaporkan hasil serupa bahwa sebagian besar responden memiliki kebiasaan makan dengan frekuensi $3 \mathrm{kali} / \mathrm{hari}$ dengan pembagian waktu makan pagi, siang dan sore atau malam.

Dalam kondisi normal setiap individu dianjurkan mengkonsumsi makanan utama 3 kali/hari dan keseimbangan zat gizi dapat diperoleh jika hidangan sehari-hari telah mencakup 3 kelompok bahan pangan. Pola makan dikatakan baik jika mengandung sumber energi, zat pembangun dan pengatur. Zat gizi tersebut dibutuhkan untuk mempertahankan sistem metabolisme tubuh sebagai penghasil tenaga, pertumbuhan dan pemeliharaan tubuh, perkembangan otak hingga produktivitas kerja sehingga perlu dikonsumsi dalam jumlah cukup sesuai kebutuhan (Mourbas, 2017). 
Berdasarkan variabel kebiasaan olahraga, diketahui sebagian besar responden kurang aktif berolahraga (80.4\%). Jenis olahraga yang paling banyak dilakukan berupa jogging (39\%), badminton (39\%) dan fitness (34.8\%). Hal ini dapat disebabkan olahraga jogging dan badminton dapat dilakukan di lingkungan sekitar tanpa membutuhkan lapangan besar. Yang termasuk dalam kegiatan fitness yakni push-up, sit-up, back-up, angkat barbel dan sejenisnya juga dapat dilakukan di rumah serta tidak membutuhkan alat yang rumit.

Rendahnya kebiasaan olahraga kelompok remaja juga ditemukan dalam studi Setiawati (2019) yang melaporkan lebih dari separuh jumlah responden (52.6\%) memiliki kebiasaan olahraga yang tergolong rendah. Studi Faradina (2019) menunjukkan hasil serupa bahwa 55\% responden penelitian memiliki kebiasaan olahraga yang tergolong rendah. Jenis olahraga yang banyak dilakukan responden yaitu lari (25.4\%), jogging/lari kecil (22.2\%) dan sepeda (11.1\%) sedangkan jenis olahraga yang jarang dilakukan yaitu sit-up (1.6\%).

Diantara faktor yang dapat menyebabkan rendahnya kebiasaan olahraga ialah terbatasnya sarana prasarana dan fasilitas olahraga ditengah pembatasan mobilitas selama pandemi COVID19. Terbatasnya sarana prasarana dan fasilitas keolahragaan diketahui dapat berdampak pada motivasi individu untuk berolahraga (Ashadi, 2020). Rendahnya kebiasaan olahraga juga dapat disebabkan hadirnya media sosial sebagai dampak kemajuan teknologi yang memicu remaja malas bergerak. Penggunaan media sosial menjadi kegiatan yang membuat remaja duduk menetap dalam jangka waktu lama. Penggunaan media sosial dalam jangka waktu lama dapat menyebabkan individu malas bergerak sehingga penggunaan energi untuk berolahraga menjadi rendah. Studi telah menunjukkan terdapat hubungan signifikan antara intensitas penggunaan media sosial dengan kebiasaan olahraga. Semakin tinggi intensitas penggunaan media sosial, maka semakin rendah kebiasaan olahraganya (Setiawati, 2019). Kendala lain yang dialami remaja untuk berolahraga ialah padatnya jadwal sekolah dan tugas yang diberikan selama belajar di rumah serta minimnya infrastruktur yang menunjang kemudahan aktivitas fisik di lingkungan sekitar seperti jalur pesepeda, taman bermain dan trotoar yang aman untuk pejalan kaki.

Idealnya, peningkatan kualitas fisik tubuh dapat dicapai dengan mengaktifkan tubuh untuk selalu bergerak dan melakukan olahraga. Olahraga yang dilakukan dengan prinsip latihan yang tepat dapat memberikan pengaruh dan adaptasi biologis yang baik bagi tubuh. Olahraga juga dapat menjadi pilihan dan upaya terbaik guna meningkatkan imunitas dan derajat kesehatan. Kebiasaan olahraga juga dapat mempengaruhi performa dan kemampuan kondisi fisik seseorang. Sebaliknya, rendahnya tingkat aktivitas individu dapat memberikan dampak negatif bagi kebugaran jasmani. Dampak negatif dari tingkat kebugaran yang rendah ialah tubuh menjadi cepat lelah, kegemukan dan rentan terhadap gejala penyakit kurang gerak. Kebugaran sangat penting untuk mendukung individu dalam melaksanakan aktivitas sehari-hari tanpa mengalami kelelahan (Ashadi, 2020).

\section{PENUTUP}

Sebagian besar remaja dalam penelitian ini memiliki tingkat kecukupan energi yang inadekuat $(71.7 \%)$, begitupula dengan tingkat kecukupan karbohidrat (78.3\%) dan protein (67.4\%). Didapatkan separuh jumlah responden (50\%) juga memiliki tingkat kecukupan lemak yang inadekuat. Berdasarkan indikator frekuensi makan, mayoritas responden $(89.1 \%)$ makan dengan frekuensi $3 \mathrm{kali} /$ hari. Variabel kebiasaan olahraga yang diteliti menunjukkan mayoritas responden (80.4\%) kurang aktif berolahraga.

Saran yang dapat diberikan pada kelompok remaja ialah untuk selalu memperhatikan pola makan dan kecukupan zat gizi yang dikonsumsi mengingat usia remaja merupakan masa pertumbuhan yang membutuhkan zat gizi lebih tinggi dan meningkatkan kebiasaan olahraga guna mencapai kebugaran fisik. Penelitian ini hanya 
mengidentifikasi gambaran pola makan dan kebiasaan olahraga pada kelompok remaja dengan analisis deskriptif. Disarankan bagi peneliti selanjutnya untuk melakukan studi dengan analisis yang lebih mendalam menggunakan analisis bivariat hingga multivariat guna mengetahui faktor-faktor yang berhubungan dengan pola makan dan kebiasaan olahraga remaja sehingga dapat dijadikan acuan dalam melakukan intervensi kesehatan berkaitan dengan pola makan dan kebiasaan olahraga.

\section{DAFTAR PUSTAKA}

Amaliyah, M., Soeyono, R. D., Nurlaela, L., and Kristiastuti, D. 2021. 'Pola Konsumsi Makan Remaja di Masa Pandemi COVID-19', Jurnal Tata Boga, 10(1): 129-137.

Amelia, A. R., Syam, A. and Fatimah, S. 2013. 'Hubungan Asupan Energi dan Zat Gizi dengan Status Gizi Santri Putri Yayasan Pondok Pesantren Hidayatullah Makassar Sulawesi Selatan Tahun 2013', Jurnal Universitas Hasanuddin Makassar.

Anggraeni, S. D. 2015. Hubungan antara Body Image dengan Frekuensi Maka, Jenis Makanan dan Status Gizi Remaja Putri di SMA Negeri 7 Surakarta. Skripsi. Surakarta:Universitas Muhammadiyah Surakarta.

Ashadi, K., Andriana, L. M. and Pramono, B. A. 2020. 'Pola Aktivitas Olahraga Sebelum dan Selama Masa Pandemi COVID-19 pada Mahasiswa Fakultas Olahraga dan Fakultas Non-Olahraga', Jurnal SPORTIF: Jurnal Penelitian Pembelajaran, 6(3): 713-728.

Badan Penelitian dan Pengembangan Kesehatan. 2019. Laporan Nasional Riskesdas 2018. Jakarta: Lembaga Penerbit Badan Penelitian dan Pengembangan Kesehatan.

Faradina, R. 2019. Gambaran Aktivitas Sedentari, Kebiasaan Olahraga dan Besar Uang Saku Kaitannya dengan Kejadian Obesitas pada Remaja Putri di SMP Negeri 40 Semarang. Laporan Akhir DIII. Semarang:Politeknik Kesehatan Kemenkes Semarang.

Hafiza, D., Utami, A. and Niriyah, S. 2020. 'Hubungan Kebiasaan Makan dengan Status Gizi pada Remaja SMP YLPI Pekanbaru', Jurnal Medika Hutama, 02(01): 332-342.

Kumala, M. and Bardosono, S. 2014 'Masalah Gizi Ganda pada Remaja Usia 15-19 Tahun di
Lima Wilayah Jakarta', Journal of the Indonesian Medical Association, 64(1): 31-37.

Kusumo, M. P. 2020. Buku Pemantauan Aktivitas Fisik. Sleman: The Journal Publishing.

Mokoginta, F. S., Budiarso, F. and Manampiring, A. E. 2016. 'Gambaran Pola Asupan Makanan pada Remaja di Kabupaten Bolaang Mongondow Utara', Jurnal e-Biomedik (eBm), 4(2): 1-10.

Mondelez International and The Harris Poll. 2020. The Second Annual State of Snacking.

Mourbas. 2017. Kebutuhan Gizi Remaja. Media Info. Padang: Departemen Kesehatan Republik Indonesia.

Rah, J. H. et al. 2021. "The Triple Burden of Malnutrition Among Adolescents in Indonesia', SAGE JOURNALS: Food and Nutrition Bulletin, 42(1): S4-S8.

Rokhmah, F., Muniroh, L. and Nindya, T. S. 2016. 'Hubungan Tingkat Kecukupan Energi dan Zat Gizi Makro dengan Status Gizi Siswi SMA di Pondok Pesantren Al-Izzah Kota Batu', Media Gizi Indonesia, 11(1): 94-100.

Roring, N. M., Posangi, J. and Manampiring, A. E. 2020. 'Hubungan antara Pengetahuan Gizi, Aktivitas Fisik dan Intensitas Olahraga dengan Status Gizi', Jurnal Biomedik, 12(2): 110-116.

Setiawati, F. S., Mahmudiono, T., Ramadhani, N., and Hidayati, K. F. 2019 'Intensitas Penggunaan Media Sosial, Kebiasaan Olahraga, dan Obesitas pada Remaja di SMA Negeri 6 Surabaya Tahun 2019', Amerta Nutrition, pp. 142-148.

Sholichah, F., Aqnah, Y. I. and Sari, C. R. 2021. 'Asupan Energi dan Zat Gizi Makro terhadap Persen Lemak Tubuh', Jurnal Ilmiah Gizi dan Kesehatan (JIGK), 02(02): 15-22.

Sirajuddin, Surmita and Astuti, T. 2018. Bahan Ajar Gizi Survey Konsumsi Pangan. Jakarta Selatan.

Suci, S. P. 2011. Faktor-Faktor yang Berhubungan dengan Pola Makan Mahasiswa Kesehatan Masyarakat Fakultas Kedokteran dan Ilmu Kesehatan Universitas Islam Negeri Syarif Hidayatullah Jakarta Tahun 2011. Universitas Islam Negeri Syarif Hidayatullah Jakarta.

United Nations Children's Fund. 2020. Situasi Anak di Indonesia - Tren, Peluang dan Tantangan Dalam Memenuhi Hak-Hak Anak. Jakarta: UNICEF Indonesia.

United Nations Children's Fund. 2021. Strategi Komunikasi Perubahan Sosial dan Perilaku: 
Aisyah, N, F., Mustakim., Intan, R, S. / Pola Makan dan / JPPKMI 2 (2) (2021)

Meningkatkan Gizi Remaja di Indonesia. Jakarta: UNICEF.

Utami, H. D., Kamsiah and Siregar, A. 2020. 'Hubungan Pola Makan, Tingkat Kecukupan
Energi dan Protein dengan Status Gizi pada Remaja', Jurnal Kesehatan, 11(2): 279-286. 